\title{
Diagnostics of hypercortisolism - comparison between the clinical usefulness of salivary and serum cortisol measurements
}

\author{
Diagnostyka hiperkortyzolizmu — porównanie przydatności klinicznej oznaczeń \\ kortyzolu w ślinie i w surowicy
}

Łukasz Żukowski, Janusz Myśliwiec, Maria Górska

Department of Endocrinology, Diabetology and Internal Diseases, Medical University of Bialystok, Poland

\begin{abstract}
Introduction: The aim of this study was the comparison of $24 \mathrm{~h}$ urine free cortisol (UFC), serum cortisol at 11pm (SCM) and late-night salivary cortisol (LSC) in patients suspected for hypercortisolism, and an assessment of the usefulness of these measurements in diagnosing overt Cushing's (OCS) syndrome, pseudo Cushing's state (PCS) and subclinical Cushing's syndrome (SCS).

Material and methods: The study group consisted of 82 patients, of whom four patients had SCS, three OCS and eight PCS. For measurements of LSC, the ELISA method was used, and for UFC and SCM determination, chemiluminescent microparticle immunoassay was used. Results: The highest correlation coefficient characterised LSC and SCM $(r=0.72)$. Area under curve (AUC) for SCM and LSC in receiver operating characteristic (ROC) for OCS was: 0.86 v. 0.74; for PCS: $0.83 v .0 .70$; and for SCS: $0.74 v .0 .79$.

Conclusions: Our findings suggest that LSC is more useful compared to SCM in diagnosing subclinical Cushing's syndrome. Moreover, LSC seems to be a valuable diagnostic criterion to distinguish pseudo Cushing's state. However, to obtain reliable cut-offs for LSC values, a larger group of hypercortisolic patients is needed. (Endokrynol Pol 2013; 64 (4): 263-267)
\end{abstract}

Key words: salivary cortisol, serum cortisol, urinary cortisol, overt Cushing's syndrome, sublinical Cushing's syndrome, pseudo Cushing's state

\section{Streszczenie}

Wstęp: Celem pracy było porównanie oznaczeń kortyzolu w surowicy o 23 godz. (SCM), późnowieczornego stężenia kortyzolu w ślinie (LSC), wolnego kortyzolu z dobowej zbiórki moczu (UFC) u pacjentów z podejrzeniem endogennej hiperkortyzolemii oraz ocena przydatności tych oznaczeń w diagnostyce jawnego zespołu Cushinga (OCS), rzekomego zespołu Cushinga (PCS) oraz subklinicznego zespołu Cushinga (SCS).

Material i metody: Badania przeprowadzono u 82 pacjentów, wśród których u 4 zdiagnozowano SCS, u 3 OCS oraz u 8 PCS. Do oznaczenia LSC użyto metody immunoenzymatycznej, UFC oraz SCM oznaczono metodą immunochemiluminescencji. Wyniki: Najwyższy współczynnik korelacji charakteryzował LSC oraz SCM $(r=0,72)$. Pole pod krzywą (AUC) dla SCM i LSC w analizie charakterystyki operacyjnej odbiornika (ROC) dla OSC wynosiło odpowiednio 0,86 v. 0,74 dla PCS: 0,83 v. 0,70 dla SCS: 0,74 v. 0,79.

Wnioski: Uzyskane wyniki wskazują, że LSC jest bardziej przydatny w porównaniu do SCM w diagnostyce subklinicznego zespołu Cushinga. LSC również wydaje się być wartościowym kryterium diagnostycznym w różnicowaniu rzekomego zespołu Cushinga. Jednakże do określenia wiarygodnych punktów odcięcia dla LSC potrzebne są badania przeprowadzone w większej grupie chorych z hyperkortyzolizmem. (Endokrynol Pol 2013; 64 (4): 263-267)

Słowa kluczowe: kortyzol w ślinie, kortyzol w surowicy, wolny kortyzol w moczu, jawny zespół Cushinga, subkliniczny zespół Cushinga, rzekomy zespół Cushinga

\section{Introduction}

The most frequent indications to perform diagnostics of hypercortisolism are typical signs and symptoms for Cushing's syndrome (CS) and/or adrenal incidentaloma (AI). Although the most common type of hypercortisolism is ACTH-dependent Cushing's syndrome, there is increasing incidence of adrenal incidentaloma due to the widespread use of advanced imaging techniques like ultrasonography or computed tomography. The incidence of AI increases with a patient's age and reaches over $7 \%$ in the general population aged over 70 years [1]. The $5-20 \%$ of AI cases that have been reported to show mild cortisol excess without any specific signs and symptoms of CS are termed subclinical Cushing's syndrome (SCS) [2-6]. Overt CS usually develops demonstrative signs like reddish-purple striae, plethora, proximal muscle weakness, bruising with no obvious trauma, and unexplained osteoporosis [7]. In such patients, 
confirmation of CS by biochemical tests is usually easy, while diagnosis of SCS remains controversial.

Another problem of clinical importance is to distinguish CS with pseudo Cushing's states (PCS) related to overactivity of the hypothalamic-pituitary-adrenal axis in patients complaining of depression, visceral obesity, polycystic ovaries syndrome, poorly controlled diabetes, anorexia, menstrual irregularity and chronic alcoholism [8]. On the one hand, depression, diabetes, obesity, hypertension, osteoporosis or menstrual irregularity may constitute symptoms of cortisol excess. On the other hand, these conditions are common in the general population $[9,10]$.

A challenge for the endocrinologist is to differentiate between SCS and PCS in a patient with AI. Dexamethasone-suppressed corticotropin-releasing hormone stimulation test and the desmopressin test performed in endocrinology departments do not guarantee absolute diagnostic accuracy, while the number of such patients continues to increase [11].

Thus, reliable, easy to perform and cheap methods are needed for hypercortisolism diagnostics that would be convenient in outpatients. Current clinical guidelines recommend the initial use of one of the following tests: 24-h urinary free cortisol (UFC), late-night salivary cortisol (LSC) and serum cortisol after $1 \mathrm{mg}$ overnight dexamethasone suppression test (DST) [12]. Late-night salivary cortisol seems the best choice as an initial test, compared to DST, UFC and serum cortisol measurement (SCM) because of its highest sensitivity [13]. Moreover, LSC is a noninvasive procedure, free of stress and easy to collect and store. In addition, saliva contains stable cortisol and is unaffected by alterations in cortisol-binding globulin [14].

Thus, the aim of this study was a comparison of UFC, SCM and LSC in patients suspected for hypercortisolism and an assessment of their usefulness in diagnosing CS, PCS and SCS.

\section{Material and methods}

The study group consisted of 82 patients admitted to the Department of Endocrinology, Diabetology and Internal Diseases of the Medical University in Bialystok between 2009 and 2011 who were diagnosed because of a suspicion of hypercortisolism. The most frequent indication for screening of Cushing's syndrome was the presence of signs and symptoms suggestive of hypercortisolism: 43 of the $82(52 \%)$. In 33 cases (40\%), patients were diagnosed with $\mathrm{AI}$, and six $(7 \%)$ had pituitary adenoma.

Saliva and serum were collected at 8am and $11 \mathrm{pm}$. 24-hour urine collection was used for UFC determination. DST was performed typically by measurement of serum cortisol in morning sample (8am) after administration of $1 \mathrm{mg}$ dexamethasone at $11 \mathrm{pm}$ the previous night. Salivary cortisol was measured using a Lucio - Medical ELISA Salivary Cortisol HS kit (analytic sensitivity $<0.012 \mathrm{ng} / \mathrm{mL}$, specificity for cortisol $100 \%$, intra- and interassay $\mathrm{CV}$ was respectively $<4.94 \%$ and $<4.07 \%$ ). Chemiluminescent microparticle immunoassay (CMIA) by ARCHITECT of Abbott Laboratories was used to determine cortisol in serum and in urine (functional sensitivity assay of $<1 \mu \mathrm{g} / \mathrm{dL}$, specificity for cortisol was $100 \%$ assay precision of $<10 \%$ total CV for serum samples $>3$ to $<35 \mu \mathrm{g} / \mathrm{dL}$ and $<20 \%$ total $\mathrm{CV}$ for urine samples $>3$ to $<35 \mu \mathrm{g} / \mathrm{dL}$.)

In patients with $\mathrm{AI}$, a 16-slice $\mathrm{CT}$ was performed with description of tissue density using Hounsfield's scale.

Three types of hypercortisolism were distinguished. Subclinical Cushing's syndrome was diagnosed in four cases who had cortisol in serum above $1.8 \mu \mathrm{g} / \mathrm{dL}$ in DST (the indication for screening in all SCS patients was AI), three patients with overt CS (two with pituitary adenoma and one with ectopic ACTH-producing tumour) and eight patients with PCS. The PCS group consisted of four patients with depression (including one with poorly controlled diabetes), three obese (BMI $>30$ ), and one with anorexia.

To evaluate relationships between LSC, SCM and UFC, Spearman's test was performed using Statistica 10.0 (StatSoft, Tulsa, OK, USA). In each type of hypercortisolism, receiver operating characteristic (ROC) analysis for LSC and SCM was performed using STATA 11.

\section{Results}

We observed positive correlations in all variables. The highest $R$ value $(R=0.72)$ characterised the correlation between LSC and SCM (Fig. 1). Relatively low R values characterised UFC in correlation with LSC and SCM ( $R=0.37$ and $R=0.47$ respectively), thus $R O C$ analysis for this variable was not performed. In ROC analysis for LSC and SCM, graphs indicate slightly higher area under the curve (AUC) for LSC (AUC $=0.79$ ) compared to SCM (AUC $=0.74)$ for patients with SCS (Fig. 2). Cut-off point for LSC in this case was $0.82 \mu \mathrm{g} / \mathrm{dL}$ with sensitivity $75 \%$ and specificity $89 \%$. On the other hand, in patients with overt Cushing's syndrome (Fig. 3), AUC was significantly higher for cortisol in serum (AUC $=0.86$ ) than in saliva (AUC $=0.74$ ). Sensitivity and specificity reached $80 \%$ for $6.2 \mu \mathrm{g} / \mathrm{dL}$. For LSC measurement, sensitivity reached $100 \%$ at specificity $49 \%$ with $0.16 \mu \mathrm{g} / \mathrm{dL}$. In patients with PCS (Fig. 4), serum cortisol more often indicated patients with hypercortisolemia: ROC area: 0.83 v. 0.70 . 


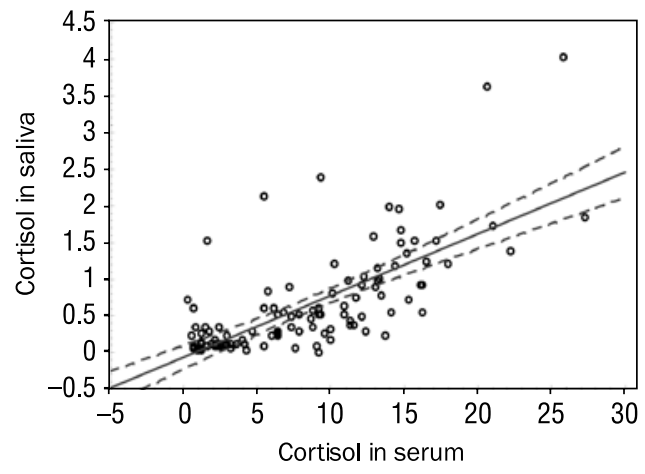

Figure 1. Spearman's rank correlation of late-night salivary cortisol and serum $(R=0.72)$

Rycina 1. Korelacja rang Spearman'a dla późnowieczornego kortyzolu we ślinie $i$ w surowicy $(R=0,72)$

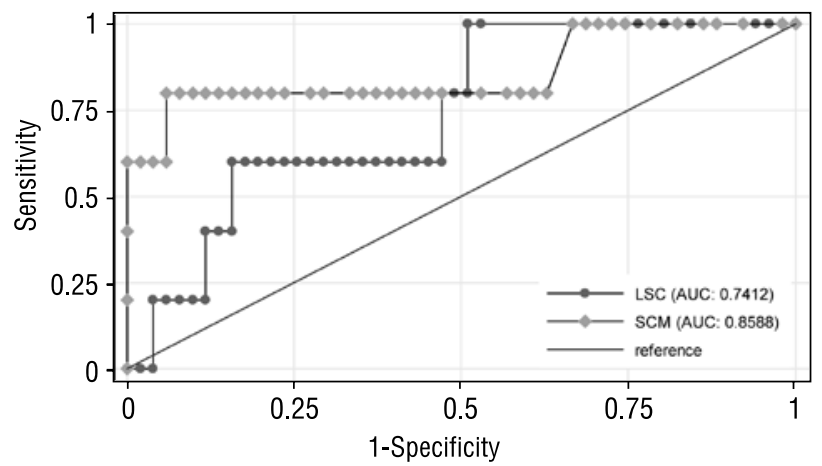

Figure 3. ROC curves and AUC analysis for overt Cushing's syndrome

Rycina 3. Krzywe ROC oraz AUC dla jawnego zespotu Cushinga

\section{Discussion}

Results of the present study have shown a satisfactory correlation between LSC and SCM, which does not agree with previous publications [15-17]. For this reason, this method is carefully investigated in patients suspected for hypercortisolism. Recently published studies have shown that LSC is a convenient screening test for overt Cushing's syndrome $[10,18,19]$. The cut-off values for LSC in OCS reported in these studies varied from 0.13 to $0.55 \mu \mathrm{g} / \mathrm{dL}$, with high sensitivities and specificities. More problematic is establishing the cut-off value in diagnosis of SCS. In our study, LSC measurement in SCS cases reached sensitivity of 75\% and specificity of $89 \%$ for $0.82 \mu \mathrm{g} / \mathrm{dL}$. A low sensitivity $(22.7 \%)$, but high specificity $(87.7 \%)$ for cut-off $0.18 \mu \mathrm{g}$ $\mathrm{dL}$ characterised LSC in the study by Masserini et al. [20]. In the analysis of Nunes et al., sensitivity and specificity were comparable (77\% and 69\% respectively) for $0.17 \mu \mathrm{g} / \mathrm{dL}$ [21]. By contrast, Yuko Tateishi et al. indicated $0.11 \mu \mathrm{g} / \mathrm{dL}$ value of LSC with $100 \%$ sensitivity but only $50 \%$ specificity [22].

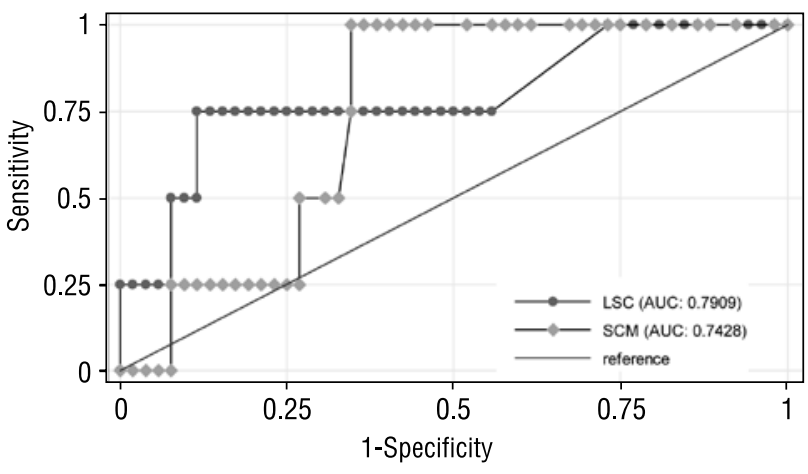

Figure 2. ROC and AUC analysis for subclinical Cushing's syndrome

Rycina 2. Krzywe ROC oraz AUC dla subklinicznego zespotu Cushinga

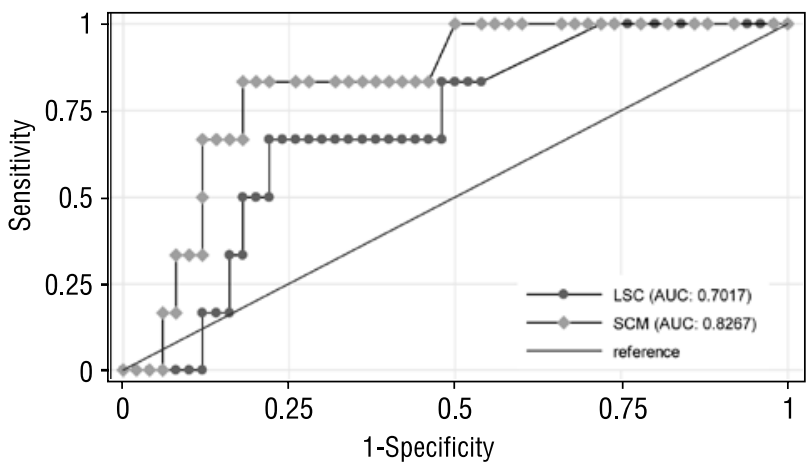

Figure 4. ROC and AUC analysis for pseudo Cushing's state

Rycina 4. Krzywe ROC oraz AUC dla rzekomego zespotu Cushinga

Differences between presented results may be explained by different diagnostic criteria for SCS and different assay methods used. Salivary cortisol has been usually measured by RIA and ELISA $[18,19,23,25,26]$ and much more rarely by electrochemiluminescent immunoassay (ECLIA) or liquid chromatography tandem mass spectrometry (LC-MS/ /MS) $[23,27,28]$. The study by Beko et al. revealed better performance of LSC using ECLIA (sensitivity 100\% and specificity $88 \%$ ) compared to RIA (sensitivity 100\% and specificity 71\%) [23]. Another study demonstrated an important rate of abnormal LSC results in volunteers without evidence of Cushing's syndrome when measured using two different commercial assays and evaluated with laboratory provided normative ranges [24]. Assays of RIA and ELISA can be affected by cross-reactivity with cortisol metabolites and synthetic glucocorticoids. Liquid chromatography tandem mass spectrometry does not pose this problem, but some drugs such as carbamazepine or fenofibrate may interfere in this method and cause falsely elevated values [29]. In addition, patients with 
SCS and adrenal incidentaloma are characterised by a fluctuated cortisol secretion and may not reveal abnormal cortisol in a single measurement [30].

Our study suggests that LSC is better than SCM as a diagnostic criterion of PCS, as far as it enables reduction of false positive results of Cushing's syndrome. Thus, LSC seems a reliable method especially in patients with elevated cortisol binding globulin in serum (e.g. obese or those taking carbamazepine or oral contraceptives).

Another aspect of salivary cortisol procedure is sample collection and storage. Saliva collection should be done between $11 \mathrm{pm}$ and midnight. In healthy individuals with stable circadian rhythm, the level of serum cortisol begins to rise at $3 \mathrm{am}-4 \mathrm{am}$, reaching its peak at $7 \mathrm{am}-9$ am and then falling by the end of the day to its lowest value. Loss of circadian rhythm is typical for Cushing's syndrome but also can occur due to the stress of hospitalisation. Most clinicians ask patients to collect saliva samples on two separate evenings at home. Saliva is collected by drooling into a plastic tube or by placing a cotton pledget in the mouth and chewing for 1-2 min. The sample is stable at room temperature for several weeks. In healthy volunteers, salivary cortisol concentrations are highly correlated with those in plasma, urine and cerebrospinal fluid and have been assumed to represent only free cortisol [31-35]. Several factors may substantially influence salivary cortisol measurements. The salivary glands express $11 \beta$-hydroxysteroid dehydrogenase type 2 , so patients chewing tobacco or using products containing liquorice may have falsely elevated LSC. Patients who smoke cigarettes have been shown to have higher LSC than non-smokers [36]. On the other hand, avoiding smoking can cause changes in cortisol levels for smokers, possibly due to the stress of non-smoking [32]. When first including salivary cortisol as a study aim, scientists used various substances to stimulate saliva such as citric acid, gum or instant fruit drinks. Results showed that some substances, especially acidic substances, can give erroneously high readings $[37,38]$.

\section{Conclusion}

Our findings suggest that LSC is more useful than SCM in diagnosing SCS. LSC also seems to be a valuable diagnostic criterion to distinguish pseudo Cushing's state. However, to obtain reliable cut-offs for LSC, a larger group of hypercortisolic cases is needed.

\section{References}

1. Young WF Jr. Management approaches to adrenal incidentalomas. A view from Rochester, Minnesota. Endocrinol Metab Clin North Am 2000; 29: 159-185.
2. Mansmann G, Lau J, Balk E et al. The clinically in apparent adrenal mass: update in diagnosis and management. Endocr Rev 2004; 25: 309-340.

3. Young WF Jr. Clinical practice. The incidentally discovered adrenal mass. N Engl J Med 2007; 356: 601-610.

4. Rossi R, Tauchmanova L, Luciano A et al. Subclinical Cushing's syndrome in patients with adrena lincidentaloma: clinical and biochemical features. J Clin Endocrinol Metab 2000; 85: 1440-1448.

5. Chiodini I. Diagnosis and Treatment of Subclinical Hypercortisolism. J Clin Endocrinol Metab 2011; 96: 1223-1236.

6. Zeiger MA, Siegelman SS, Hamrahian AH. Medical and surgical evaluation and treatment of adrenal incidentalomas. J Clin Endocrinol Metab 2011; 96: 2004.

7. Ross EJ, Linch DC. Cushing's syndrome - killing disease: discriminatory value of signs and symptoms aiding early diagnosis. Lancet 1982; 2: 646-649.

8. Newell-Price J, Bertagna X, Grossman AB, Nieman LK. Cushing Syndrome. Lancet 2006; 367: 1605-17.

9. Ness-Abramof R, Nabriski D, Apovian CM et al. Overnight dexamethasone suppression test: a reliable screen for Cushing's syndrome in the obese. Obes Res 2002; 10: 1217-1221.

10. Chiodini I, Mascia ML, Muscarella S et al. Subclinical hypercortisolism among outpatients referred for osteoporosis. Ann Intern Med 2007; 147: 541-548.

11. Pecori Giraldi F, Pivonello R, Ambrogio AG et al. The dexamethasonesuppressed corticotropin-releasing hormone stimulation test and the desmopressin test to distinguish Cushing's syndrome from pseudoCushing's states. Clin Endocrinol 2007; 66: 251-257.

12. Nieman LK, Biller BMK, Finding JW et al. The diagnosis of Cushing's syndrome: an endocrine society clinical practice guideline. J Clin Endocrinol Metab 2008; 93: 1526-1540.

13. Papanicolaou DA, Mullen N, Kyrou I et al. Nighttime salivary cortisol: a useful test for the diagnosis of Cushing's syndrome. J Clin Endocrinol Metab 2002; 87: 4515-4521.

14. Putignano P, Toja P, Dubini A et al. Midnight salivary cortisol versus urinary free and midnight serum cortisol as screening tests for Cushing's syndrome. J Clin Endocrinol Metab 2003; 88: 4153-4157.

15. Umeda T, Hiramatsu R, Iwaoka T et al. Use of saliva for monitoring unbound free cortisol levels in serum. Clin Chim Acta 1981; 110: 245-253.

16. Vining RF, McGinley RA, Maksvytis JJ et al. Salivary cortisol: a better measure of adrenal cortical function than serum cortisol. Ann Clin Biochem 1983; 20: 329-335.

17. Restituto P, Galofré JC, Gil MJ et al. Advantage of salivary cortisol measurements in the diagnosis of glucocorticoid related disorders. Clin Biochem 2008; 41: 688-692.

18. Yaneva M, Mosnier-Pudar H, Dugue MA et al. Midnight salivary cortisol for the initial diagnosis of Cushing's syndrome of various causes. J Clin Endocrinol Metab 2004; 89: 3345-3351.

19. Viardot A, Huber P, Puder JJ et al. Reproducibility of nighttime salivary cortisol and its use in the diagnosis of hypercortisolism compared with urinary free cortisol and overnight dexamethasone suppression test. J Clin Endocrinol Metab 2005; 90: 5730-5736.

20. Masserini B, Morelli V, Bergamaschi S et al. The limited role of midnight salivary cortisol levels in the diagnosis of subclinical hypercortisolism in patients with adrenal incidentaloma. Eur J Endocrinol 2009; 160: 87-92.

21. Nunes ML, Vattaut S, Corcuff JB et al. A late night salivary cortisol for diagnosis of overt and subclinical Cushing's syndrome in hospitalized and ambulatory patients. J Clin Endocrinol Metab 2009; 94: 456-462.

22. Tateishi Y, Kouyama R, Mihara M et al. Evaluation of salivary cortisol measurements for the diagnosis of subclinical Cushing's syndrome Endocrinol J 2012; 59: 283-289.

23. Beko G, Varga I, Glaz E. A Cutoff values of midnight salivary cortisol for the diagnosis of overt hypercortisolism are highly influenced by methods. Clin Chim Acta 2010; 411: 364-367.

24. Baid SK, Sinaii N, Wade M et al. Radioimmunoassay and Tandem Mass Spectrometry Measurement of Bedtime Salivary Cortisol Levels: A Comparison of Assays to Establish Hypercortisolism. J Clin Endocrinol Metab 2007; 92: 3102-3107.

25. Doi M, Sekizawa N, Tani Y et al. Late-night salivary cortisol as a screening test for the diagnosis of Cushing's syndrome in Japan. Endocr J 2008; 55: 121-126.

26. Kidambi S, Raff H, Findling JW. Limitations of nocturnal salivary cortisol and urine free cortisol in the diagnosis of mild Cushing's syndrome. Eur J Endocrinol 2007; 157: 725-731.

27. Carrozza C, Corsello SM, Paragliola RM et al. Clinical accuracy of midnight salivary cortisol measured by automated electrochemiluminescence immunoassay method in Cushing's syndrome. Ann Clin Biochem 2010; 47: 228-232. 
28. Zerikly RK, Amiri L, Faiman C et al. Diagnostic characteristics of latenight salivary cortisol using liquid chromatography-tandem mass spectrometry. J Clin Endocrinol Metab 2010; 95: 4555-4559.

29. Lin CL, Wu TJ, Machacek DA et al. Urinary free cortisol and cortisone determined by high performance liquid chromatography in the diagnosis of Cushing's syndrome. J Clin Endocrinol Metab 1997; 82: 151-155.

30. Barzon L, Fallo F, Sonino N et al. Development of overt Cushing's syndrome in patients with adrenal incidentaloma. Eur J Endocrinol 2002; 146: 61-66.

31. Stetler C, Miller GE. Depression and hypothalamic-pituitary-adrena activation: A quantitative summary of four decades of research. Psychosomatic Medicine 2011; 73: 114-126.

32. Lewis JG. Steroid analysis in saliva: An overview. Clin Biochem Rev 2006; 27: 139-146.

33. Dorn LD, Lucke JF, Loucks TL et al. Salivary cortisol reflects serum cortisol: analysis of circadian profiles. Ann Clin Biochem 2007; 44: 281-284.
34. Poll EM, Kreitschmann-Andermahr I, Langejuergen $Y$ et al. Saliva collection method affects predictability of serum cortisol. Clin Chim Acta 2007; 382: 15-19.

35. Tornhage CJ. Salivary cortisol for assessment of hypothalamic-pituitary-adrenal axis function. Neuroimmunomodulation 2009; 16 : 284-289.

36. Badrick E, Kirschbaum C, Kumari M. The relationship between smoking status and cortisol secretion. J Clin Endocrinol Metab 2007; 92: 819-824.

37. Gordon MK, Peloso E, Auker A, Dozier M. Effect of flavored beverage crystals on salivary cortisol enzyme-immunoreactive assay measurements. Dev Psychobiol 2005; 47: 189-195.

38. Clements AD, Parker CR Jr, Salley BJ et al. Marshmallows used as saliva stimulant do not affect cortisol concentrations: Finally a palatable alternative for toddler saliva collection. Dev Psychobiol 2007; 49: 702-707. 